\title{
Corporate Governance and Non-Jordanian Share Ownership: the Case of Amman Stock Exchange
}

\author{
Mishiel Suwaidan ${ }^{1}$, Suzan Abed $^{2} \&$ Abeer Al-Khoury ${ }^{3}$ \\ ${ }^{1}$ Faculty of Economics and Administrative Sciences, Yarmouk University, Jordan \\ ${ }^{2}$ Faculty of Economics and Administrative Sciences, Applied Science University, Jordan \\ ${ }^{3}$ PUST University, Jordan \\ Correspondence: Suzan Abed, Faculty of Economics and Administrative Sciences, Applied Science University, \\ Jordan. E-mail: susanabed_2002@hotmail.com
}

Received: April 15, 2013

Accepted: August 23, 2013 Online Published: September 22, 2013

doi:10.5539/ijbm.v8n20p14

URL: http://dx.doi.org/10.5539/ijbm.v8n20p14

\begin{abstract}
In many countries institutional investors have become dominant players in the financial markets. This paper aims to examine whether better corporate governance practices increase attractiveness of Jordanian shares for foreign investors. In order to achieve the above objective a sample of 183 company listed on the Amman Stock Exchange for the year 2010 is employed. The results reveal that institutional ownership, ownership concentration, total assets and audit size are related to non-Jordanian investor. This result builds on the importance of non-Jordan shareholders in enhancing corporate governance mechanism.
\end{abstract}

Keywords: corporate governance, institutional ownership, ownership concentration, foreign ownership, non-Jordanian share ownership

\section{Introduction}

In the last two decades, corporate governance issues have become a top priority for the international business community (Hossain, 2007). The adoption of effective corporate governance practices enhances transparency of a company's operation and improves performance. Ownership structure plays a vital role in effective corporate governance. Dyck (2000) highlighted that in countries with weak governance standards, foreign owners are likely to export their higher standards and apply them to firms in the host country.

Participation of foreign investors in domestic financial markets has increased over the last years (Ramaswamy \& $\mathrm{Li}, 2001)$. Bekaert et al. (2002) highlighted that foreign investors play an important role in improving corporate governance in emerging markets context. Bushman and Smith (2003) pointed out that effective corporate governance structure reduces foreign investors' risks and increases their confidence and willingness to invest in particular listed companies. Also, it helps to ensure that minority shareholders receive reliable information about the performance of the company and that the value of their investment is not expropriated by managers and controlling shareholders. It has been argued that foreign investors play an important role in minimizing agency conflict; they can act as a monitoring device for managers' behavior. Agency relation according to Jensen and Meckling (1976: 308) is "a contract under which one or more (principal) engage another person (the agent) to perform some service on their behalf which involves delegating some decision-making authority to the agent". That is, there is a separation of ownership and control which will lead to the existence of information asymmetry. This occurs when one party (the manager) has more information than the other (outside investors). As a result, the management holds superior knowledge about the firm's future performance (Healy \& Palepu, 2001)

Ajinkya et al. (2005) indicated that effective corporate governance structures constrain corporate managers and/or controlling shareholders from expropriating other investors by monitoring an environment of greater transparency, then foreign investors are more likely to be more dependent on effective corporate governance structure. The rationale for this argument is that foreign investors are usually minority shareholders and face higher risk of being expropriating by corporate managers and/or controlling shareholders. The recent literature acknowledges the role of foreign investors as important media in monitoring shareholder's interest. Foreign investors have emerged as a powerful constitution that plays a very significant role in improving corporate governance. 
Previous research provides evidence consistent with the notion that firms with foreign ownership are significantly more effective and efficient than those without foreign ownership (Hallward-Driemeier, 2001). Doms and Jensen (1998) found that firms with foreign ownership are more productive, more capital intensive and pay higher wages than firms without foreign ownership. Lim and Kim (2005) found that Korean mutifirm conglomerates with nonvoting shares and more listed firms tend to have a lower family stake and better corporate governance. Thus, it has been argued that some of the key reasons for foreign investors not to invest in emerging markets are both poor corporate governance and weak transparency (McKinsey and Company, 2001; Banz \& Clough, 2002; Gibson, 2003).

The objective of this study is to examine whether corporate governance mechanisms are associated with non-Jordanian share ownership in companies listed on the Amman stock exchange (ASE). More specifically, this study aims to investigate the impact of listed companies' board size, proportion of non-executive directors, institutional share ownership, the existence of audit committee, ownership concentration, market capitalization, return on equity, and liquidity on the percentage of ownership held by none Jordanians (Arab \& foreign investors).

From the above perspectives, the focus of this study is limited to two areas of concern: corporate governance and non-Jordanian ownership. Specifically, this study intends to investigate whether differences in non-Jordanian share ownership across listed companies on the Amman stock exchange (ASE) are related to company-specific differences in corporate governance mechanisms.

The remainder of this study is set out as follows: section 2 reviews previous studies. Section 3 discusses the background of corporate governance in Jordan. Section 4 develops hypotheses of the study. Section 5 presents the research methodology. Section 6 discusses the empirical results of the study. Section 7 provides a summary to the research findings and presents the main conclusions of the study.

\section{Literature Review}

A number of studies have been undertaken about the relationship between corporate governance and foreign ownership (Bokpin \& Isshaq, 2009; Leuz at al. 2009; Hossain, 2007; Mangena \& Tauringana, 2007; Tsamenyi et al., 2007; Chevalier et al., 2006). Mangena \& Tauringana (2007) examined the impact of corporate governance and disclosure on foreign share ownership for a sample of companies listed on the Zimbabwe Stock Exchange. They found positive association between foreign share ownership and both the independence of audit committee and the percent of non-executive directors in the firm's board.

Leuz at al. (2009) also investigated the relationship between foreign investors and corporate governance. Using 4,409 firm-observations from twenty-nine countries, the results revealed that firms with poor governance structure are more taxing to foreign investors in terms of their information and monitoring costs, which could explain why foreign investors avoid these firms. So, effective corporate governance structure plays an important role when foreign investors make their investment decisions.

In Ghana, Bokpin \& Isshaq (2009) investigated the impact of transparency and corporate governance on foreign share ownership for a sample of listed firms on the Ghana stock exchange (GSE). They found that when foreign investors make their investment decisions they consider corporate governance and disclosure practices employed in the listed firms. Thus, foreign investors avoid investing in firms with poor corporate governance structures and inadequate disclosure practices.

Kim et al. (2010) examined the impact of poor corporate governance on equity participation of foreign investors. The results indicated that foreign equity ownership is negatively associated with firms' ownership concentration but is positively associated with firms' efforts for better corporate governance.

Haldar and Rao (2012) examined the relationship between corporate governance and foreign portfolio investment in India. Based on 500 industrial firms, the results of regression analysis indicated that foreign portfolio investment in India is significantly affected by financial attributes and corporate governance factors.

In Jordan, Al-Najjar (2010) examined the factors that determine institutional investors' investment decisions using non-financial Jordanian data. The results showed that the Jordanian institutional investors consider firms' capital structure, profitability, business risk, asset structure, liquidity, growth and firm size when they take their investment decisions.

\section{Corporate Governance Environment in Jordan}

Corporate governance mechanisms have become one of the most important issues discussed in the world economies. US congress has responded to the collapse of Enron and Arthur Anderson, the failure of WorldCom 
by enacting a law, the Sarbanes-Oxley Act of 2002, to enforce good corporate governance and ethical business practices for the publically traded companies.

Jordan is a small country with limited resources; its financial market is aiming to the principles of equality, transparency and effectiveness. However, Jordan like other countries also experienced financial collapses such as Shamaylaeh Gate (JFED, 2003), which forces regulatory bodies to adopt a sequence of legislative, economic and financial reforms that intended to promote transparency, accountability and the rule of law in the economic life of the country (JFED, 2003).

In 2005, the Jordan Securities Commission (JSC)'s announced the first Jordanian corporate governance codes for corporations listed in the ASE for the purpose of establishing a solid framework that regulates their relations and defines their responsibilities to safeguard shareholders. Additionally, the code addressed issues of ownership structure and capital market. However, the adoption of the code is not compulsory. The disclosure department in JSC is in charge of applying these rules, because many of these rules are binding legal provisions, which means that corporate governance codes are general rules and the details left to the relevant legislation such as the Securities Law and related regulation, the Company Law, and the international principles established by the Organization of Economic Corporation and Development (OECD).

According to the Organization of Economic Cooperation and Development (OECD) there are five major principles of corporate governance. These are, the rights of shareholders, the equitable treatment of shareholders, the role of stakeholders in corporate governance, disclosure and transparency and the responsibilities of the board. The Jordanian corporate governance codes comply with the OECD principles of corporate governance (Al-Najjar, 2010).

\section{Development of Research Hypotheses}

The following sub-sections set up the research hypotheses and provide the rationale for each hypothesis.

\subsection{Non-Executive Directors}

Non-executive directors are the non-working directors in a firm who do not participate in the day-to-day management of the firm. They also are called independent directors, or outside directors. The existence of non-executive directors in the firm's board may have positive influence on foreign investors' decisions. Foreign investors consider non-executive directors as effective mechanism in monitoring and controlling the exploitation behaviors of managers, and thus, provide a better protection of the interest of shareholders (Mangena and Tauringana, 2007).

H1: There is a positive relationship between the percentage of non-executive directors in the firm's board and the ownership held by non-Jordanians.

\subsection{Board Size}

The size of the board of directors has been cited in previous researches to have an impact on the quality of corporate governance. Nevertheless, several studies supported the idea that large boards can be dysfunctional. Hermalin and Weisbach (2003) indicated that the board size can be viewed as a proxy for the board's activity, suggesting that smaller board sizes are better than larger ones in solving monitoring problems. Yermack (1996) and Eisenberg et al. (1998) found a negative relation between board size and firm value, indicating that smaller boards are more effective since they experience fewer communication and coordination problems.

H2: There is a negative relationship between the board size and the ownership held by non-Jordanians.

\subsection{Institutional Ownership}

The percentage of shares owned or controlled by institutional shareholders may affect the investment decisions of foreign investors. Karamanou and Vafeas (2005) suggested that foreign investors perceive institutional investors as more effective than individual investors to monitor managers through information advantage that they have. In addition, institutional investors can be seen as more active market maker, and more active market traders than individual investors (World Bank, 2003). Therefore, it is expected that foreign investors are more likely to be interested in companies in which high percentage of their shares are owned by institutional investors.

H3: There is a positive relationship between the institutional ownership ratio and the ownership held by non-Jordanians. 


\subsection{Ownership Concentration}

Most of the companies in Jordan are closely held either by families, Arab, foreign or institutional owners. Shleifer \& Wolfenson (2002) argued that ownership concentration becomes an important tool in solving agency problem between controlling and minority shareholders. The empirical evidence on corporate governance suggests that large owners have strong opportunities to exercise control over managers than small owners. Cruickshank (1991) highlighted that small shareholders have difficulties in monitoring managers' behavior, since managers have full access to prevent unwanted outcomes. That is, the greater the distance between the principal and the agent, is the more likely to be an increase in information asymmetry between the contracting parties

H4: There is a positive relationship between the ownership concentration and the ownership held by non-Jordanians.

\subsection{Audit Committee}

The existence of audit committee can be seen as a mechanism for reducing information asymmetry between managers and owners and also for protecting investors (McMullen, 1996; McDaniel et al., 2002). Klein (2002) indicated that the existence of independent audit committee tends to reduce the possibility of earnings management, thus improving transparency. Empirically, Mangena and Tauringana (2007) found a positive association between foreign share ownership and the existence of audit committee.

H5: There is a positive relationship between the existence of audit committee and the ownership held by non-Jordanians.

\subsection{Split Chairman/CEO Roles (Duality)}

Jensen (1993) argued that separating chairman and CEO roles serves better shareholders' interest. Yermack (1996) provided evidence that large firms that separate the two functions have higher return on assets and cost efficiency ratios than firms where the same person holds both titles. Also, Abdul Rahman and Haniffa (2003) found that Malaysian firms with role duality did not perform well compared with their counterparts. However, Blackburn (1994) argued this separation provides an essential check over management's performance.

H6: There is a positive relationship between the split chairman/CEO roles and the ownership held by non-Jordanians.

\section{Research Methodology}

This part of the study discusses the sample selection criterion and presents the dependent and independents variables employed in the study. Also the last sub-section presents the model employed in order to test the study hypotheses.

\subsection{Sample Selection}

This study employed all companies listed on the Amman Stock Exchange for the year ended 2010 and for which all necessary data were available. Data were collected from the companies' annual reports and from the ASE website. As of December 31, 2010, the number of listed companies on ASE was 224. Of the 224 listed companies, annual reports for 183 companies were available and useable. This number represents $82 \%$ of the listed companies on the Amman Financial Market (AFM) at the end of 2010 (see Table 1).

Table 1. Sample selection criteria

\begin{tabular}{cc}
\hline Year 2010 & Number \\
\hline Population: Total listed companies & 224 \\
Less: Companies with no or insufficient data & 41 \\
Final sample & 183 \\
Proportion of sample to total listed companies & 0.82 \\
\hline
\end{tabular}

\subsection{Dependent Variable- Non-Jordanian Ownership}

Information on non-Jordanian ownership was obtained from ASE website. Table (2) shows the total percentage of shares owned by non-Jordanians and growth for all listed companies for the period 2007-2012. 
Table 2. Percentage of shares owned by non-jordanians share ownership

\begin{tabular}{ccc}
\hline Years & $\%$ of Non-Jordanian Investors & Growth \\
\hline 2006 & $54.5 \%$ & - \\
2007 & $51.1 \%$ & $-6.7 \%$ \\
2008 & $50.8 \%$ & $-0.59 \%$ \\
2009 & $51.2 \%$ & $1.74 \%$ \\
2010 & $50.4 \%$ & $-1.56 \%$ \\
2011 & $48.7 \%$ & $-3.37 \%$ \\
Sep. 2012 & $47.7 \%$ & $-2.05 \%$ \\
\hline
\end{tabular}

As seen from Table 2, the percentage of shares owned by non-Jordanians decreased from $54.5 \%$ in 2006 to $47.7 \%$ in 2012. This decease can be partially explained by the occurrence of financial crises in 2008 .

\subsection{Independent Variables-Corporate Governance}

As discussed earlier and in consistent with previous studies, the current study employs common measures of effective corporate governance. These are: proportion of non-executive directors, board size, institutional ownership, existence of audit committee, ownership concentration and role duality.

\subsection{Control Variables}

We control for a number of other variables that could be expected to have influence on non-Jordanian investors. As expected, foreign investors are interested in companies with high return, large companies, small levered firm and companies audited by the Big 4 audit firms. Lin and Shiu (2003), Jiang and Kim (2004) and Al-Najjar (2010) provided evidence supporting a positive relationship between foreign ownership and company size. Managen and Tauringana (2007) also indicated that return on equity was positively associated with foreign share ownership. Lin and Shiu (2003) indicated that foreign investors avoid companies with high debt in their capital structure. Finally, Guedhami et al. (2009) showed that privatized firms worldwide become less (more) likely to appoint a Big 4 auditor with the extent of state (foreign) ownership.

\subsection{Model Specification}

To examine the impact of corporate governance characteristics on non-Jordanian ownership, the following ordinary least squire (OLS) regression model is used:

$$
\begin{gathered}
N J O W=\beta_{0}+\beta_{1} \text { PROPNED }+\beta_{2} B S I Z E+ \\
+\beta_{3} I O R+\beta_{4} C O M+\beta_{5} C O N C+\beta_{6} D U A L+\beta_{7} T A+\beta_{8} R O E \\
+\beta_{9} D R+\beta_{10} A U D+\varepsilon j
\end{gathered}
$$

Table 3 provides a summary of the variables used by the model and their measurements.

\begin{tabular}{|c|c|}
\hline Variables & Definition \\
\hline NJOW & $\begin{array}{l}\text { Non-Jordanian ownership, measured by the percentage of shares held by non-Jordanian investors at the end of financial } \\
\text { year. }\end{array}$ \\
\hline PROPNED & Percentage of non-executive directors in the firm's board \\
\hline BSIZE & Board size, measured by the number of directors on the firm's board. \\
\hline IOR & Institutional ownership ratio, measured by the percentage of shares owned by institutional owners. \\
\hline $\mathrm{COM}$ & Existence of audit committee, 1 if there is an audit committee, and 0 otherwise. \\
\hline CONC & Ownership concentration, measured by percentage of shares owned by major shareholders. \\
\hline DUAL & Duality of the CEO, 1 if there is a duality, and 0 otherwise. \\
\hline TA & Total assets, measured by the total assets of the company at the annual report at the end of the year. \\
\hline ROE & Return on equity, measured by net income divided by total of stockholders equity at the annual report date. \\
\hline DR & Debt ratio, measured as a ratio of total liabilities divided by total assets at the annual report date. \\
\hline Aud & 1 if the company audited by international firm, and 0 otherwise \\
\hline$\beta 0 ß 10$ & Regression coefficients \\
\hline $\mathrm{Ej}$ & Error term \\
\hline
\end{tabular}

Table 3. Definition of variables included in the regression model 


\section{Empirical Results}

This section presents the results of the study.

\subsection{Descriptive Statistics}

Table 4 provides a summary of descriptive statistics about all the variables included in the analysis. As seen, on average, a 21.4 percent of a company is owned by non-Jordanians. Also, as indicated by the range and the standard deviation, the non-Jordanian ownership varies considerably between the sample companies.

Table 4. Descriptive statistics

\begin{tabular}{lcccl}
\hline & Min & Max & Mean & Std. D \\
\hline NJOW & .00 & .9851 & .2139 & .2221 \\
PROPNED & .40 & 1.000 & .9036 & .10352 \\
BSIZE & 3.0 & 14.00 & 8.630 & 2.388 \\
IOR & .02 & .9900 & .4806 & .2534 \\
CONC & .21 & .9900 & .7550 & .1555 \\
TA & 5.6 & 10.36 & 7.470 & .7400 \\
ROE & .53 & .5700 & .0284 & .1392 \\
DR & .00 & .9100 & .3380 & .2436 \\
\hline
\end{tabular}

As for independent variables which consist of seven continuous variables and three dummy variables, it can be observed that size of the board ranges from 3 to 14 . It can also be seen that, on average, $90 \%$ of a company's board consist of independent directors. This suggests that board of directors in Jordan enjoys a considerable high level of independence. It is noticeable that, on average, the top-10 shareholders (ownership concentration) own almost $75 \%$ of a company. Overall, there are dispersions in the above variables as revealed by the standard deviations.

As for the dummies, Table 5 exhibits the frequency and the percentage of companies with and without separation between the role of CEO and Chairman. The table shows that almost in $49 \%$ of the sample companies, the chairman of the board holds the CEO position.

Table 5. Descriptive statistics of duality of CEO

\begin{tabular}{lll}
\hline Duality of CEO & Frequency & $\%$ \\
\hline No Duality & 93 & 50.8 \\
Duality & 90 & 49.2 \\
Total & 183 & 100.0 \\
\hline
\end{tabular}

Table 6 presents the existence of audit committee in the sample companies. The table indicates that around $36 \%$ of the sample companies have audit committee.

Table 6. Existence of audit committee

\begin{tabular}{lll}
\hline Audit Committee & Frequency & $\%$ \\
\hline Yes & 65 & 35.5 \\
No & 118 & 64.5 \\
Total & 183 & 100.0 \\
\hline
\end{tabular}

Table 7 presents the frequency and the percentage of companies audited by international audit firm. The result shows that $24.6 \%$ of the study sample audited by international audit firm. 
Table 7. Auditing firm

\begin{tabular}{ccc}
\hline Audit Firm & Frequency & $\%$ \\
\hline Domestic Firm & 138 & 75.4 \\
International Firm & 45 & 24.6 \\
Total & 183 & 100.0 \\
\hline
\end{tabular}

\subsection{Multiple Regression Results}

Before conducting the regression analysis, several assumptions need to be satisfied. These include no multicollinearity, homoscedasticity and normality. The VIF indicates the correlation between predictors and others (Field, 2005); when the VIF is more than 10, this indicates a problem of multicollinearity. The VIF values for all independent variables are almost less than 3.0, which imply that no multicollinearity problem exists in the model as it appears in table 8 .

In order to test for homoscedasticity, scatterplot of standardized predicted value against standardized residuals is performed. The visual inspection of the residual appears to be randomly scattered around the horizontal line 0 , then the assumption is satisfied. Figure 1 exhibit that the scatterplot of the residuals indicates that homoscedasticity has been met.

\section{Dependent Variable}

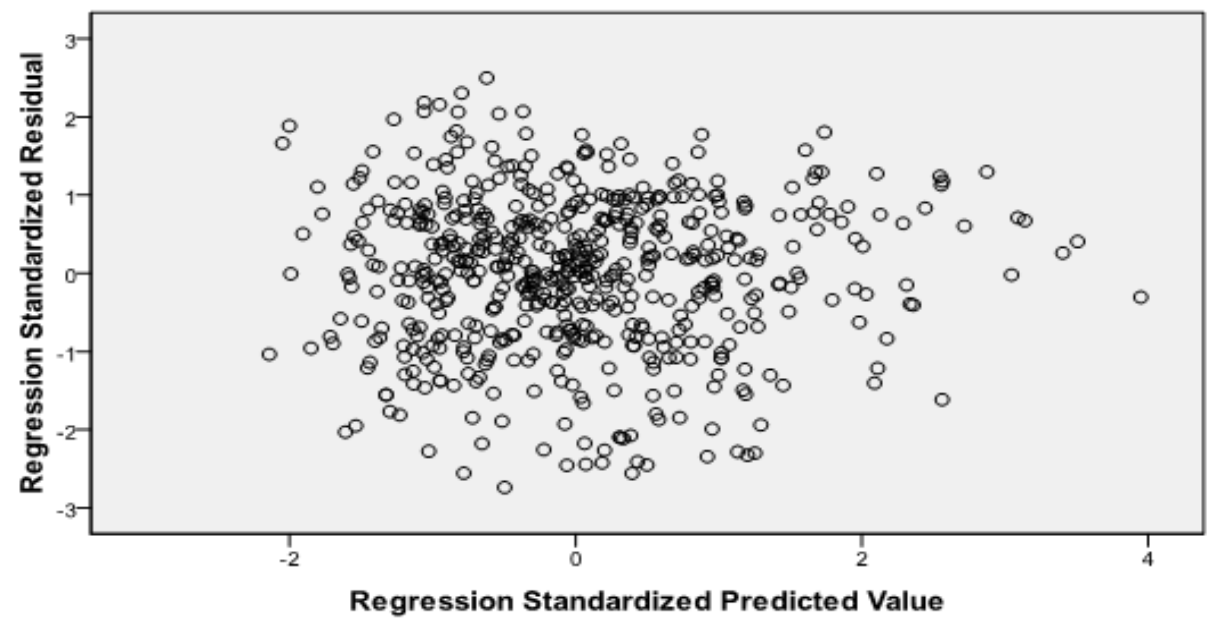

Figure 1. Scatterplot of residuals

The rule of thumb for a normality test based on skewness and kurtosis analysis indicates normality with a skewness of \pm 1.96 and a kurtosis of \pm 2 (Cooke, 1989). The results show that there is no normality problem in the dataset. 
Table 8. Regression results of the relationship of non-Jordanian share ownership with corporate governance

\begin{tabular}{lllll}
\hline Variables & Coefficients & t-statistic & P-Value & VIF \\
\hline Constant & -39.562 & -1.314 & .191 & 1.195 \\
PROPNED & -15.203 & -.982 & .328 & 1.433 \\
BSIZE & -.567 & -.770 & .442 & 1.469 \\
IOR & 14.345 & 2.040 & $.043^{* *}$ & 1.097 \\
COM & 3.162 & .987 & .325 & 1.354 \\
CONC & 21.761 & 1.991 & $.048^{* *}$ & 1.167 \\
DUAL & -2.261 & -.715 & .476 & 3.028 \\
TA & 6.847 & 1.981 & $.049^{* *}$ & 1.295 \\
ROE & 1.523 & .127 & .899 & 1.756 \\
DR & 6.732 & .829 & .408 & 1.547 \\
Aud & 7.522 & 1.779 & $.077^{*}$ & \\
$R^{2}$ & 0.253 & & & \\
Adjusted $R^{2}$ & 0.209 & & & \\
Durbin-Watson & 1.951 & & & \\
Model F Test & 5.818 & P-value $=.000$ & & \\
\hline
\end{tabular}

** Significant at the $5 \%$ level.

* Significant at the $10 \%$ level.

Table 8 presents the results of the multiple regression analysis. As seen, the regression model is significant at the $1 \%$ level $(\mathrm{F}=5.818, \mathrm{P}=.000)$. It can also be seen that the ten independent variables incorporated in the model explain about $21 \%$ of the variation in the non-Jordanians ownership in the sample companies (Field, 2005). As for the explanatory variables, three variables were found significant at the $5 \%$ level. These variables are: $\log$ total assets, institutional ownership ratio and ownership concentration. These results suggest that non-Jordanian investors prefer to invest in companies in which the majority of owners are institutional. This could also suggest that for non-Jordanian investors the existence of institutional owners in the company is viewed as a proxy for effective monitoring.

The study also found that non-Jordanian ownership is positively associated with the companies having higher ownership concentration (shareholders own more than 1\%). We interpret these results as an indication that non-Jordanian investors prefer companies that have few major owners, mostly, institutional.

As for control variables, consistent with most previous studies, the study found that non-Jordanian investors prefer to invest in large companies. Finally, the study found that non-Jordanian investors prefer to invest in companies audited by international firms rather than local firms. However, this variable was found significant, though, at $10 \%$.

\section{Conclusions and Implications}

This study examined the relationship of foreign share ownership and corporate governance mechanisms in Jordan. Previous studies have suggested that foreign investors look for companies in which their investments are more likely to be protected. Using a dataset relating to listed ASE companies for the year 2010, we found that non-Jordanian share ownership is positively associated with companies which have both higher ownership concentration (shareholders own more than 1\%) and higher institutional ownership ratio. As for other corporate governance measures (board size, audit committee, board independence, and duality), we found no significant relationship with non-Jordanian share ownership.

We also found that non-Jordanian share ownership is positively associated with total assets. This result is consistent with previous studies such as Jiang \& Kim (2004) and Managen \& Tauringana (2007). Additionally, the result showed positive relation between foreign share ownership and international audit firm, though, at $10 \%$ significance level. On the other hand, debt ratio had no significant effect on foreign-Arab share ownership, which is inconsistent with previous studies (e.g., Kang \& Stulz, 1997; Dahlquist \& Robertsson, 2001; Lin \& Shiu, 2003). This study highlights the importance of the non-Jordan investors as the main owners of Jordanian firms, to the legislative authorities to enhance the corporate governance decisions in Jordan.

We therefore recommend that even though this study considers only Jordan, it demonstrates that Arab countries must adopt good governance practices as a way of attracting foreign investment. Firms must constantly review 
their corporate governance mechanism, since investors take these issues into consideration in their investment decisions.

We believe that investigating the determinants of foreign share ownership, particularly the effect of corporate governance, is a fundamental research problem, of which the findings of this study may inform public policy decisions, as well as provide guidance for corporate managers on the needs of foreign investors. From the perspective of policy-makers, investigating foreign share ownership in emerging markets is important to improve the flow of foreign capital into these markets. If effective corporate governance is important determinant of foreign share ownership, regulatory changes may be considered to improve corporate governance structures.

From the perspective of companies, foreign investor participation should improve the market value of their shares and thus lower their cost of capital. Understanding the impact effective corporate governance (and indeed other factors) on foreign share ownership will enable companies to address these issues effectively. On the academic front, the findings could improve our understanding of foreign share ownership in developing countries as well as the consequences of effective corporate governance for listed companies in these countries. Further research is absolutely needed on this topic, while ignoring the problem of endogeneity between corporate governance mechanism and ownership structure may lead to misleading results.

\section{References}

Abdul Rahman, R., \& Haniffa, R. M. (2003). Effectiveness of Internal Governance Mechanisms: An Empirical Analysis of Malaysian Companies for the Period 1992-2000. Proceedings of ANZAM Conference, Australia.

Ajinkya, B., Bhojraj, S., \& Sengupta, P. (2005). The Association Between Outside Directors, Institutional Investors and the Properties of Management Forecasts. Journal of Accounting Research, 43, 343-376. http://dx.doi.org/10.1111/j.1475-679x.2005.00174.x

Al-Najjar, B. (2010). Corporate Governance and Institutional Ownership: Evidence from Jordan. Corporate Governance, 10(2), 176-190. http://dx.doi.org/10.1108/14720701011035693

Banz, R., \& Clough, S. (2002). Globalization Reshaping World's Financial Markets. Journal of Financial Planning, 15, 72-80.

Bekaert, G., Harvey, C. R., \& Lumsdaine, R. L. (2002). Dating the Integration of World Equity Markets. Journal of Financial Economics, 65, 203-247. http://dx.doi.org/10.1016/S0304-405X(02)00139-3

Blackburn, V. (1994). The Effectiveness of Corporate Control in the US Corporations. Corporate Governance-An International Review, 2, 196-202.

Bokpin, G. A., \& Isshaq, Z. (2009). Corporate Governance, Disclosure and Foreign Share Ownership on the Ghana Stock Exchange. Managerial Auditing Journal, 24(7), 688-703. http://dx.doi.org/10.1108/02686900910975387

Bozec, Y., \& Bozec, R. (2007). Ownership Concentration and Corporate Governance Practices: Substitution or Expropriation Effects? Canadian Journal of Administrative Sciences, 24(3), 182-195.

Bushman, R., \& Smith, A. (2003). Transparency, Financial Accounting Information, and Corporate Governance. FRBNY Economic Policy Review, 65-87.

Chevalier, A., Prasetyantoko, A., \& Rokhim, R. (2006). Foreign Ownership and Corporate Governance in Indonesia. Conference Paper, University of Paris.

Cooke, T. E. (1989). Disclosure in the Corporate Annual Reports of Swedish Companies. Accounting and Business Research, 19(74), 113-124.

Cruickshank, J. (1991). The Small Shareholder and the Big Company. Management Accounting, 69(1), 20-21.

Dahlquist, M., \& Robertsson, G. (2001). Direct Foreign Ownership, Institutional Investors, and Firm $\begin{array}{llll}\text { Characteristics. Journal of Financial } & \text { Economics, } & 59(3), & \text { 413- }\end{array}$ http://dx.doi.org/10.1016/S0304-405X(00)00092-1

Doms, M., \& Jensen, J. (1998). Comparing Wages, Skills, and Productivity between Domestic and Foreign Owned Manufacturing Establishments in the United States. In Baldwin, R., Lipsey, R., \& Richardson, J. (Eds.), Geography and Ownership as Bases for Economic Accounting. University of Chicago Press.

Dyck, A. (2000). Ownership Structure, Legal Protections and Corporate Governance. In Pleskovic, B., \& Stiglitz, J. (Eds.), Proceedings of the Annual World Bank Conference on Development Economics (pp. 
293-332). World Bank.

Eisenberg, T., Sundgren, S., \& Well, M. T. (1998). Larger Board Size and Decreasing Firm Value in Small Firms. Journal of Financial Economics, 48, 113-139.

Field, A. (2005). Discovering Statistics Using SPSS (2nd ed.). London: SAGE Publications.

Gibson, M. S. (2003). Is Corporate Governance Ineffective in Emerging Markets? Journal of Financial and Quantitative Analysis, 38, 231-250. http://dx.doi.org/10.2307/4126771

Guedhami, O., Pittman, J. A., \& Saffar, W. (2009). Auditor Choice in Privatized Firms: Empirical Evidence on the Role of State and Foreign Owners. Journal of Accounting and Economics, 48, 151-171. http://dx.doi:10.1016/j.jacceco.2009.08.003

Hallward-Driemeier, M. (2001). Firm-level Survey Provides Data on Asia's Corporate Crisis and Recovery. Policy Research Working Paper Series 2515, The World Bank.

Healy, P., \& Palepu, K. (2001). Information Asymmetry, Corporate Disclosure, and the Capital Markets: A Review of the Empirical Disclosure Literature. Journal of Accounting and Economics, 31, 405-440. http://dx.doi.org/10.1016/S0165-4101(01)00018-0

Hermalin, B. E., \& Weisbach, M. S. (2003). Boards of Directors as an Endogenously Determined Institution: A Survey of the Economic Literature. Economic Policy Review, Federal Reserve Bank of New York, 7-26.

Hossain, M. (2007). The Corporate Governance Reporting Exercise: The Portrait of a Developing Country. International Journal of Business Research, 7(2), 211-221.

Jensen, M. (1993). The Modern Industrial Revaluation Exit and the Failure of Internal Control Systems. Journal of Finance, 48, 831-880. http://dx.doi.org/10.1111/j.1540-6261.1993.tb04022.x

Jensen, M. C., \& Meckling, W. H. (1976). Theory of Firm: Managerial Behavior, Agency Costs and Ownership Structure. Journal of Financial Economics, 3(4), 146-153.

JFED (Jordanian Forum for Economic Development). (2003). The State of Corporate Governance in Jordan, The Economic Policy Dialogue, 1, 1-6.

Jiang, L., \& Kim, J. B. (2004). Foreign Equity Ownership and Information Asymmetry: Evidence from Japan. Journal of International Financial Management, 15, 185-211.

Kang, J. K., \& Stulz, R. M. (1997). Why is there A Home Bias? An Analysis of Foreign Portfolio Equity Ownership in Japan. Journal of Financial Economics, 46, 3-28. http://dx.doi.org/10.1016/S0304-405X(97)00023-8

Karamanou, I., \& Vafeas, N. (2005). The Association between Corporate Boards, Audit Committees and Management Earnings Forecasts: An Empirical Analysis. Journal of Accounting Research, 43(3), 453-485. http://dx.doi.org/10.1111/j.1475-679X.2005.00177.x

Kim, I. J., Kim, J. E., Kim, W. S., \& Byun, S. J. (2010). Foreign Investors and Corporate Governance in Korea. Pacific-Basin Finance Journal, 18(4), 390-402. http://dx.doi.org/10.1016/j.pacfin.2010.04.002

Klein, A. (2002). Audit Committee, Board of Size, Director Characteristics and Earnings Management. Journal of Accounting and Economics, 35, 375-400. http://dx.doi.org/10.1016/S0165-4101(02)00059-9

Leuz, C., Lins, K., \& Warnock, F. (2009). Do Foreigners Invest Less in Poorly Governed Firms? The Review of Financial Studies, 22(8), 3245-3285. http://dx.doi.org/10.1093/rfs/hhn089

Lim, U., \& Kim, C. S. (2005). Determinants of Ownership Structure: An Empirical Study of the Korean Conglomerates. Pacific-Basin Finance Journal, 13(1), 1-28. http://dx.doi.org/10.1016/j.pacfin.2003.11.001

Lin, C. H., \& Shiu, C. (2003). Foreign Ownership in the Taiwan Stock Market-An Empirical Study. Journal of Multinational Financial Management, 13, 19-41. http://dx.doi.org/10.1016/S1042-444X(02)00021-X

Managen, M., \& Tauringana, V. (2007). Disclosure, Corporate Governance and Foreign Share Ownership on the Zimbabwe Stock Exchange. Journal of International Financial Management \& Accounting, 18(2), 53-85.

McDaniel, L., Martin, R., \& Maines, L. (2002). Evaluating Financial Reporting Quality: The Effects of Financial Expertise versus Financial Literacy. The Accounting Review, 77, 139-167. http://dx.doi.org/10.2308/accr.2002.77.s-1.139

McKinsey Company. (2001). Giving New Life to the Corporate Governance Reform Agenda for Emerging Markets. Retrieved from http://www.Mckinsey.com/clientservice/ 
McMullen, D. (1996). Audit Committee Performance: An Investigation of the Consequences Associated with Audit Committees. Auditing: A Journal of Practice and Theory, 15(1), 87-103.

Ramaswamy, K., \& Li, M. (2001). Foreign Investors, Foreign Directors and Corporate Diversification: An Empirical Examination of Large Manufacturing Companies in India. Asia Pacific Journal of Management, 18, 207-222. http://dx.doi.org/10.1023/A:1010620008101

Shleifer, A., \& Daniel, W. (2002). Investor Protection and Equity Markets. Journal of Financial Economics, 66, 3-27. http://dx.doi.org/10.1016/S0304-405X(02)00149-6

Tsamenyi, M., Enninful-Adu, E., \& Onumah, J. (2007). Disclosure and Corporate Governance in Developing Countries: Evidence from Ghana. Managerial Auditing Journal, 22(3), 319-34. http://dx.doi.org/10.1108/02686900710733170

World Bank. (2003). Good Corporate Governance for Development in the Middle East and North Africa. Washington, DC: World Bank.

Yermack, D. (1996). Higher Market Valuation of Companies with a Small Board of Directors. Journal of Financial Economics, 40(2), 185-211.

\section{Copyrights}

Copyright for this article is retained by the author(s), with first publication rights granted to the journal.

This is an open-access article distributed under the terms and conditions of the Creative Commons Attribution license (http://creativecommons.org/licenses/by/3.0/). 